\title{
Farklı IBA (İndol-3-Bütirik Asit) Dozlarının Endemik Phlomis chimerae Boiss. Türü Çeliklerinin Köklenmesi Üzerine Etkileri
}

\author{
Ceren SELIMM ${ }^{1 *}$, Emine KAHRAMAN ${ }^{2}$ \\ ${ }^{1}$ Akdeniz Üniversitesi, Mimarlık Fakültesi, Peyzaj Mimarlığg1 Bölümü,07070, Antalya \\ ${ }^{2}$ Akdeniz Üniversitesi, Serik Gülsün Süleyman Süral Meslek Yüksek Okulu, Park ve Bahçe Bitkileri Bölümü, \\ 07500, Antalya
}

\section{Öz}

Bu çalışmada, Phlomis chimerae Boiss. türüne ait yarı odun çeliklerinin köklenme özellikleri üzerine kontrol dahil dört farklı İndol-3-Bütirik Asit (IBA) (1000, 3000, 5000 ppm ve kontrol (0 ppm IBA)) uygulamasının etkisi araştırılmıştır. Çalışma, kontrollü serada, sisleme altında ve perlit köklendirme ortamında gerçekleştirilmiştir. Deneme 3 tekerrürlü ve her tekerrürde 10 çelik olacak şekilde tesadüf parselleri deneme desenine göre planlanmıştır. Çalışma başlangıcından 14 hafta sonra sonlandırılan denemede, köklenme oranı (\%) (Kök\%), kök sayısı (kök sayısı/çelik) (KökSay), ortalama kök uzunluğu (KökUz) (cm.), kök (KökKur) (gr.) ve ramet gövde kuru (RamKur) (gr.) ağırlığı tespit edilmiştir. Araştırma sonucunda, farklı dozlardaki IBA uygulamalarının Phlomis chimerae çeliklerinde köklenmeye etkisi ölçülen bazı özellikler açısından anlamlı bulunmuştur. Çeliklere uygulanan farklı IBA dozları arasında köklenme oranı incelendiğinde IBA dozları ile köklenme oranları arasında matematiksel olarak artış olmasına rağmen bütün dozlar Duncan testi sonucuna göre aynı homojen grupta yer aldığından, köklenme oranı bakımından istatistiki olarak anlamlı fark bulunamamıştır. Kök sayısı, kök uzunluğu, kök ve ramet kuru ağırlığı değişkenlerinde ise en yüksek değerlerin 5000 ppm IBA uygulanan çeliklerinde olduğu belirlenmiştir. Genel olarak çeliklere uygulanan IBA dozu arttıkça KökSay, KökUz, KökKur, RamKur' da artış olduğu gözlemlenmiştir.

Anahtar Kelimeler: Bitkisel hormon, Indol-3 bütirik asit (IBA), Doğal tür, Çoğaltım teknikleri.

\section{Effects of Different IBA (Indole-3-Butyric Acid) Doses on Rooting of Endemic Phlomis chimerae Boiss. Cuttings}

\begin{abstract}
This study was carried out to determine the effects of different indolebutyric acid (IBA) doses (1000, 3000, 5000, and 0 (control) ppm) on rooting of semi-wood Phlomis chimerae cuttings. Cuttings were exposed to different IBA solutions in the greenhouse and planted in perlite growing medium. The experiment was planned according to completely randomized design with 3 replications and 10 cuttings per each repetition. In the study rooting ratio (\%), root number (number of roots/cutting), root length $(\mathrm{cm}$.), dry root and dry cutting weights (gr.) were measured after 14 weeks from the begining of study. The results revealed that the effect of different doses of IBA applications on rooting in Phlomis chimerae cuttings was found to be significant in terms of some measured properties. When the rooting rate between different IBA doses applied to cuttings was examined, although there was a mathematical increase between IBA doses and rooting rates, but all doses were in the same homogeneous group according to the Duncan test results, so there was no statistically significant difference in rooting rate. It was determined that the highest values were at $5000 \mathrm{ppm}$ IBA dose according to root number, root length, root and cutting dry weights. It was concluded that the increasing dose of IBA could be useful. As the IBA dose applied to cuttings increases, an increase was observed in root number, root lenght, root and cutting dry weight.
\end{abstract}

Keywords: Plant hormone, Indolbutric acid (IBA), Natural species, Propagation techniques.

\begin{tabular}{lll}
\hline *Sorumlu Yazar (Corresponding Author): & \\
Ceren SELIM (Dr. Öğr. Üyesi); Akdeniz Üniversitesi, Mimarlık Fakültesi, Peyzaj & Geliş (Received) : 24.08.2020 \\
Mimarlığı Bölümü, 07070, Antalya-Türkiye. Tel: +90 (242) 310 6546, & Kabul (Accepted) : 07.01.2021 \\
Fax: +90 (242) 310 2258, E-mail: cerenselim@akdeniz.edu.tr & Basım (Published) : 15.04.2021
\end{tabular}




\section{Giriş}

Peyzaj mimarlığında tasarım sürecinin önemli bir aşaması olan bitkisel tasarım uygulamalarında (Sarı ve Karaşah, 2018), bitkilerin yapısal özelliklerinden faydalanarak gerek kentsel gerekse kırsal planlama ve tasarımda yüksek görsel nitelikli mekanlar oluşturmaya olanak sağlar (Torun Kayabaş1, 2018; Bekçi vd., 2017; Eroğlu vd., 2005). Bitkilerin hem estetik hem de işlevsel açıdan kullanımının sağlanmasıyla tasarımcılar sürdürülebilir peyzajlar oluşturmayı hedeflemektedirler (Torun Kayabaşı, 2018). Daha az bakım gerektiren sürdürülebilir peyzajlar oluşturmak ve bitkisel tasarımlarda kullanılan bitki materyali çeşitliliğini arttırmak için dış mekan süs bitkileri kullanımında doğal türlere ilgi ve talep artmaktadır (Sever Mutlu vd., 2013). Bu kapsamda; Türkiye, AvrupaSibirya, Akdeniz ve İran-Turan fitocoğrafik bölgenin kesişiminde olması, topografya, iklim, jeomorfolojik ve ekolojik koşulların kısa mesafeler içerisinde göstermiş olduğu çeşitlilik, sahip olduğu çeşitli su kaynakları, farklı ekosistem tiplerinin bulunuşu ile kıtalar arasında bir köprü niteliğinde olması gibi nedenler dolayısıyla bitkisel çeşitlilik bakımından oldukça özel bir konuma sahip olmasına rağmen bitkisel tasarımlarda bu zenginlikten yeterince faydalanılmadığı bilinmektedir. Cengiz vd. (2017) Türkiye'nin coğrafi konumu sayesinde doğal bitki türü çeşitliliği ve endemizm açısından ön plana çıktığını ancak, peyzaj uygulamalarında bitki materyali için başvurulan fidanlık işletmelerinin doğal bitki türlerinin temini konusunda yetersiz kaldığını belirtmiştir. Bu durum doğal bitki türlerindeki envanter eksikliği, üretimde standardizasyonun sağlanamamıș olması (Ayan vd., 2020a; 2020b; 2020c), türlerin adaptasyonlarının yapılmaması (Ayan ve Sıvacıoğlu, 2006) ve fidanlıklarda satılmamasından gibi nedenlerden kaynaklanmaktadır. Bu nedenlerden dolayı egzotik türlerin kullanımını daha yaygındır (Cengiz vd., 2013; Yazıcı ve Gülgün, 2016). Bitkisel tasarımlarda egzotik türlerin kullanımı yerine doğal türlerin kültüre alınarak tercih edilmesi sürdürebilir peyzajların oluşturulmasında önemli bir diğer unsurdur (Sever Mutlu vd., 2013). Dünyanın bütün gelişmiş ülkelerinde dış mekan süs bitkileri sektörü, estetik, fonksiyonellik ve sürdürülebilirlik açısından bitkisel tasarımcılar ve uygulayıcıların ihtiyaçlarını karşılamaya çalışmakta ve bu bağlamda ürün çeşitliliği açısından zenginleşme zorunluluğu yaşamaktadır (Girmen ve Karagüzel, 2005; Davidson vd., 1994). Bu durum ülkemiz dış mekan süs bitkileri sektörü için de benzer zorunlulukların yaşanmasına neden olmaktadır. Ayrıca, ülkemiz süs bitkileri sektörü, ithalat değeri ihracat değerinden fazla olan ve dışa bağımlı bir sektördür (Kesici vd., 2010). Bu nedenle doğal türlerin sektöre kazandırılması gibi girişimler ile bu dışa bağımlılı̆̆ın ortadan kaldırılması ve hatta ihracat değerlerinin arttırılmasının sağlanması önemli bir konudur.

Oysaki doğal türlerin maliyetinin düşük ve bakımının kolay olması, adaptasyon yeteneğinin yüksek olması, yüksek sıcaklık, kuraklık gibi birçok stres koşuluna karşı daha dayanıklı olması, kentsel peyzaj uygulamalarında bitkisel çeşitliliği sağlaması, kent ekolojisine olan katkıları, kent kimliği ögesi olarak önemi gibi avantajlara sahip olması dolayısıyla bitkisel tasarımlarda daha çok kullanılması daha kolay ve yerinde bir karar olacaktır (Sıvacıŏlu vd., 2004; Torun Kayabaşı, 2018; Cengiz vd., 2013). Yurtdışından ülkemize gelen tür ve çeşitlerin birçoğunun orijinin ülkemiz oluşu, doğal kaynaklarımızın sektöre kazandırılması açısından araştırmacı ve bilim insanlarına birçok sorumluluk yüklemektedir. Sektöre kazandırılacak yeni tür ve çeşitler ekonomik, estetik ve fonksiyonel açıdan ürün çeşitliliği sağlayacak ve tasarımcılara yeni alternatifler sunacaktır. Ekonomik olarak değeri her geçen gün artmakta olan tıbbi-aromatik bitkiler sahip oldukları renk, form ve doku zenginlikleriyle bitkisel tasarımlarda daha sık rastlanan türler olmuştur. Özellikle 1990'lı yıllardan sonra, tıbbi ve aromatik bitkilerin yeni kullanım alanlarının keşfedilmesi de doğal ürünlere olan ilgiyi ve bu türlerin tercih edilmesini pozitif yönde etkilemiştir (Yıldıztekin vd., 2019; Sarıkaya, 2015). Bu bağlamda, bu çalışmaya konu olan Phlomis chimerae Boiss. (Şekil 1) peyzaj tasarımlarında estetik ve fonksiyonel açıdan kullanım potansiyeli yüksek doğal türlerimizden birisi olmasının yanında tıbbi ve aromatik bitkiler içinde de önemli bir yere sahip endemik bir türdür. Doğal floramızda var olan bu kanaatkar türün kültüre alınarak bitkisel tasarımlara ve endüstriyel kullanımlara hizmet edecek şekilde sektöre kazandırılması biyolojik çeşitliliğin devamlılığına katkı sağlayarak koruma-kullanma dengesinin kurulmasina hizmet edecektir.

Çevresel etkiler, aşırı ve bilinçsiz kullanım, peyzajlardaki değişimler sonucu oluşan habitat parçalanmaları türlerin varlığını olumsuz yönde etkileyerek erozyona uğramasına neden olmaktadır (Haag vd., 2010; Astorga vd., 2001). Özellikle doğal ve endemik türler bu olumsuzluklardan fazlasıyla etkilenmektedir (Frankham, 1997; Hamner vd., 2012). Bu bakımdan doğal türlerin koruma stratejileri belirlenirken türlerin devamlılığının sağlanması açısından çoğaltım tekniklerine yönelik çalışmaların da yapılması üzerinde durulması gereken bir konudur (Koçak, 2006). Doğal tür ve genotiplerin peyzaj tasarımlarında kullanılmasına yönelik yürütülen araştırmada türlerin uygun çoğaltım tekniklerinin (çelik ve tohum) araştırılması önemli basamaklardan birisidir (Yer ve Ayan, 2013). Türlerin bir kısmı kolayca üretilebilirken, bir kısmı ise bazı çevresel ve biyolojik etmenlerden dolayı kolayca üretilememektedir. Üretiminde zorluklar yaşanılan türler arasında nesli tehlike altında olan türlerin olduğu da bilinmektedir (Dinçer vd., 2016). Bu nedenle; türlerin hem nesillerinin yok olmasının önüne geçilmesi hem de artan ihtiyaçlara karşılık verilebilmesi bu türlerin kontrol edilen ortamlarda uygun teknikler kullanılarak çoğaltımının sağlanması ile mümkün olacaktır (Menges, 1986; Schemske vd., 1994). Bu kapsamda bitkilerde en yaygın kullanılan vejetatif çoğaltım tekniklerinden biri çelikle çoğaltımdır (Yer ve Ayan, 
2013). Çelikle çoğaltmada başarıyı etkileyen faktörler; kalıtsal yapı, depo maddeleri, bitkisel hormonlar gibi içsel faktörler ile köklenme ortamı, sıcaklık, nem vb. dışsal faktörler ve bunların etkileşimi ile belirlenir (Sever Mutlu vd., 2013). Bitkisel hormonlardan biri olan oksin grubu bileşikler; köklenmede en etkin rol oynayan faktörlerin başında gelmektedir (Davies vd., 2017). Kök ucunda üretilen ve hücre uzamasını destekleyen bir bitkisel hormon olan oksin, bitkilerin yer çekimine, 1şığa ya da suya olan tropizmal hareketlerini düzenleyen, sitokininlerle birlikte hücre bölünmesine katkı sağlayan ve köklenmeyi teşvik eden bitkisel bir hormondur (Sever Mutlu vd., 2013). İndol bütirik asitler (IBA) en yaygın kullanılan ve köklenmeyi teşvik eden ticari oksinlerdir (De Klerk vd., 1999). Doğal türlerin çelikle çoğaltımında IBA dozlarının kök kalitesi ve sayısı üzerine olumlu etkilerinin belirlenmesine yönelik çok sayıda araştırma olmasına rağmen (Karagüzel, 1997; Yahyaoğlu vd. 2002; Ayan vd., 2006; Özer ve Kalyoncu, 2007; Şeker vd., 2010; Sever Mutlu vd., 2013; Selim ve Sever Mutlu, 2018; İzgi, 2020;), P. chimerae türünün çoğaltım teknikleri ve IBA'nın çelikle çoğaltımına etkisi üzerine herhangi bir yayına rastlanmamıştır. Bu çalışmanın amacı köklendirme hormonu olarak Indol-3 bütirik asidin (IBA) farklı doz uygulamalarının $P$. chimerae türünün yarı odun çeliklerinin köklenme özellikleri üzerine etkisinin belirlenmesidir.

\section{Materyal ve Metot}

Anavatanı Türkiye olan ve doğal yayılışı Antalya ilinin Batı bölgesi ile sınırlı olan Phlomis chimeare, içinde birçok tıbbi-aromatik bitki türünü barındıran Lamiaceae (Ballıbabagiller) familyasına mensup endemik bir türdür. İsmini Yanartaş'tan (Chimarea) alan P. chimera yöresel ismiyle "Kimera şablası”" olarak anılmaktadır (Deniz ve Aykurt, 2016). 30-40 cm'ye kadar boylanabilen, odunsu karakterde çalı formlu bir türdür. Korolla sarı renkli olup tercihen kızılçam ormanlarında, deniz seviyesinden 150 m'ye kadar olan makilikler ve kayalık yamaçlarda yetişir (Çelik vd., 2005). Yapraklar üst kısımda küçük yıldızsı tüylü, alt kısımda ise beyaz keçemsi tüylüdür. NisanAğustos aylarında çiçeklenir. Kaliks 15-20 mm boyutlarındadır (Göktürk, 2015).
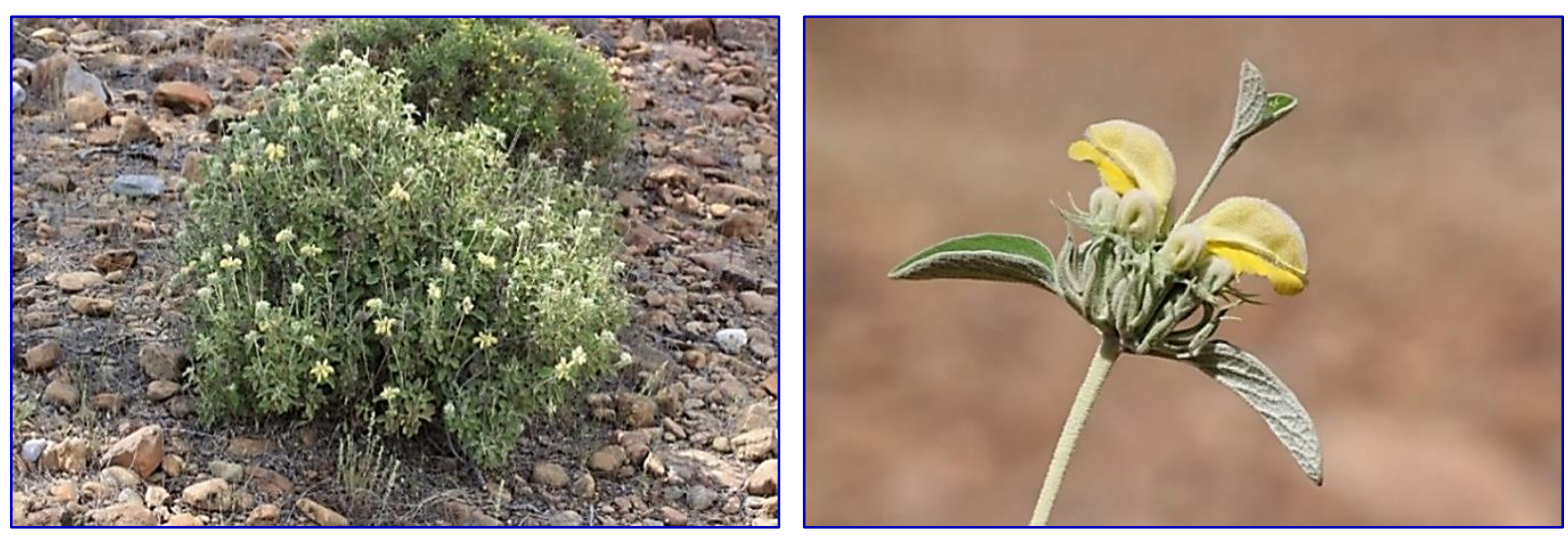

Şekil 1. Phlomis chimerae Boiss. genel görünümü (Düzlerçamı, Antalya).

Araştırmada Antalya ili Döşemealtı ilçesi Düzlerçamı mevkii’nde doğal yayılış gösteren endemik $P$. chimerae türünden Mart 2020'de alınan çelikler çalışmanın ana materyalini oluşturmuştur. Çelikler, 20 cm uzunluğunda 7$10 \mathrm{~mm}$ kalınlığında yarı odun çelikleri olarak hazırlanmıştır. 1 Mart 2020 tarihinde ortalama $20 \mathrm{~cm}$ uzunluğunda çelikler alınmıştır. Denemede Merck marka kristal yapıdaki IBA'in 3 dozu (1000 ppm, 3000 ppm, 5000 ppm konsantrasyonlarda) ve kontrol (0 ppm IBA) olmak üzere toplamda 4 işlem dozu belirlenerek muamele edilmiştir. Deneme, 3 tekerrürlü ve her tekerrürde 10 çelik olacak şekilde tesadüf parselleri deneme desenine göre planlanmıştır. 1000 ppm'lik çözeltinin elde edilmesi için 0,001 gr toz IBA, $500 \mathrm{ml}$ saf etanolde eritildikten sonra çözeltiye $500 \mathrm{ml}$ saf su eklenmiştir. 3000 ve 5000 ppm'lik çözeltinin elde edilmesi için de sırasıyla 0,003 gr ve 0,005 gr toz IBA 500'er ml saf etanol içinde çözdürülerek her birinin üzerine $500 \mathrm{ml}$ saf su eklenmiş, 1000'er ml'lik köklendirme solüsyonları hazırlanmıştır. Köklendirme solüsyonuna 5 saniye süreyle daldırılıp çıkartılan çelikler köklendirme yastıklarına dikilmiştir. Deneme Antalya Kemer ilçesinde bulunan özel bir firmaya ait plastik serada kurulmuştur. Köklendirme yastıkları yerden bir metre yükseklikte ve $120 \mathrm{~cm}$ genişlikte olup sisleme sulama sistemi mevcuttur. Serada, sisleme aralığı 20 dakikada 15 saniye olacak şekilde ayarlanmıştır. Köklendirme ortamı olarak perlit kullanılmıştır. 

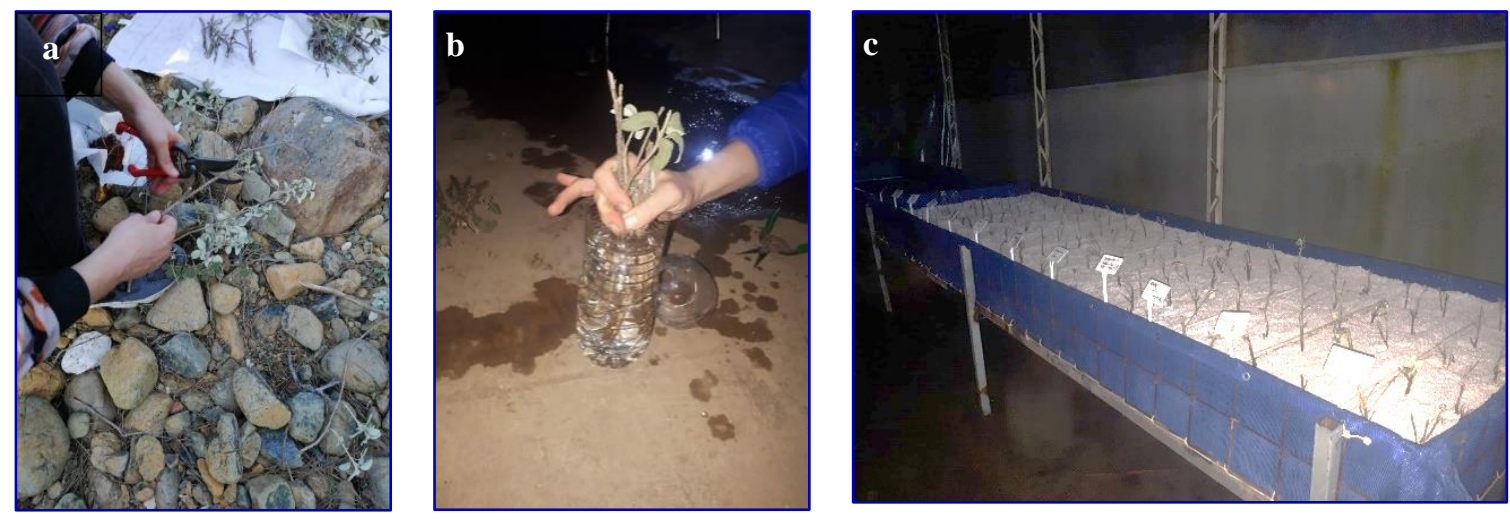

Şekil 2. Araziden alınan çelikler (a), Hazırlanan çeliklerin IBA çözeltilerine muamelesi (b), Denemeden genel görünüş (c).

Deneme başladıktan 14 hafta sonra çelikler köklendirme ortamından dikkatlice çıkarılmış ve temizlenmiştir.

Köklenme oranı (\%) (Kök\%), kök sayısı (kök sayısı/çelik) (KökSay), ortalama kök uzunluğu (KökUz) (cm.) ölçülmüştür. Kök uzunlukları dijital kumpas yardımıyla ölçülmüştür. Daha sonra kökler ve çelikler(rametler) 48 saat süreyle $72^{\circ} \mathrm{C}$ 'de etüvde kurutularak hassas terazide kuru ağılıkları tartılmıştır. Böylelikle kök (KökKur) (gr.) ve ramet kuru gövde (RamKur) (gr.) ağırlığı belirlenmiştir.

Elde edilen veriler, SPSS İstatistik Programında varyans analizi yöntemi kullanılarak analiz edilmiştir. Ortalamalar arasındaki farklar Duncan Testi ile karşılaştırılmışıtır ve hesaplanmıştır.

\section{Bulgular ve Tartışma}

Çeliklerde incelenen KökSay, KökUz, KökKur, RamKur karakterleri arasındaki farklılıklar istatistiki olarak önemli bulunmuş olup, tüm karakterlere ait ortalamalar ve Duncan testi ile tespit edilen ortalamalar arasındaki farklar Tablo 1'de verilmiştir. Köklendirilmiş rametlere ait örnek görüntüler Şekil 3'de belirtilmiştir.

Tablo 1. P. chimerae türü yarı odun çeliklerinde IBA (İndol-3-Bütirik Asit) dozu uygulamalarının köklenme özellikleri üzerine etkileri

\begin{tabular}{|c|c|c|c|c|c|}
\hline Uygulamalar & Kök\% ${ }^{* * * *}$ & KökSay & KökUz (cm.) & KökKur (gr.) & RamKur (gr.) \\
\hline Kontrol (0) & $46,66 \mathbf{a}^{*}$ & $5,76 \mathbf{a}$ & $5,00 \mathbf{a}$ & $0,847 \mathbf{a}$ & $4,29 \mathbf{a b}$ \\
\hline 1000 ppm IBA & $50,00 \mathbf{a}$ & $6,16 \mathbf{a}$ & $6,97 \mathbf{b}$ & $0,65 \mathbf{a}$ & $3,81 \mathbf{a}$ \\
\hline 3000 ppm IBA & $53,33 \mathbf{a}$ & $6,33 \mathbf{a}$ & $7,83 \mathbf{b}$ & $0,702 \mathbf{a}$ & $4,05 \mathbf{a}$ \\
\hline 5000 ppm IBA & $36,66 \mathbf{a}$ & $9,33 \mathbf{b}$ & $7,89 \mathbf{b}$ & $1,832 \mathbf{b}$ & $5,10 \mathbf{b}$ \\
\hline Ort. & 46,66 & 7,05 & 6,92 & 0,51 & 4,32 \\
\hline Min. & 0 & 1 & 1,05 & 0,001 & 1,25 \\
\hline Max. & 100 & 24 & 15 & 6,68 & 9,04 \\
\hline Std. & 50,10 & 3,56 & 2,48 & 1,53 & 1,82 \\
\hline F değeri & 0,212 & $0,196^{* * * *}$ & $0,098^{* *}$ & $0,859^{\text {** }}$ & $0,07 * *$ \\
\hline
\end{tabular}

*Aynı sütunda bulunan aynı harfler $(\mathrm{a}, \mathrm{b})$ istatistiksel olarak önemli farklılık olmadığını göstermektedir.

**, *** sirasıyla \%5 ve \%1 seviyesinde önemlidir. Her sütunda ortalamalar arasındaki farklılıklar Duncan testiyle belirlenmiştir.

**** Kök\%; Köklenme oranı, KökSay; Kök sayısı, KökUz; Ortalama kök uzunluğu, KökKur; Kök kuru ağırlığı, RamKur; Ramet kuru ağırlığını ifade etmektedir.

\subsection{Köklenme Oranı}

Çeliklere uygulanan bütün IBA uygulamaları birlikte değerlendirildiğinde $P$. chimerae türünde ortalama köklenme oranının $\% 46,6$ olduğu ve bu oranının $\% 0$ ile $\% 80$ oranında varyasyon gösterdiği belirlenmiştir. Kontrol grubu çeliklerde ortalama köklenme oranı \%46,6, 1000 ppm IBA uygulanan çeliklerde ortalama 
köklenme oranı \%50, 3000 ppm IBA uygulanan çeliklerde ortalama köklenme oranı \%53,33 ve 5000 ppm IBA uygulanan çeliklerde ortalama köklenme oranı ise \%36,6'dır. Tablo 1'de görüldüğü gibi köklenme oranları bakımından matematiksel olarak artış olmasına rağmen bütün dozlar Duncan testi sonucuna göre aynı homojen grupta yer aldığından, köklenme oranı bakımından istatistiki olarak anlamlı fark bulunamamıştır.
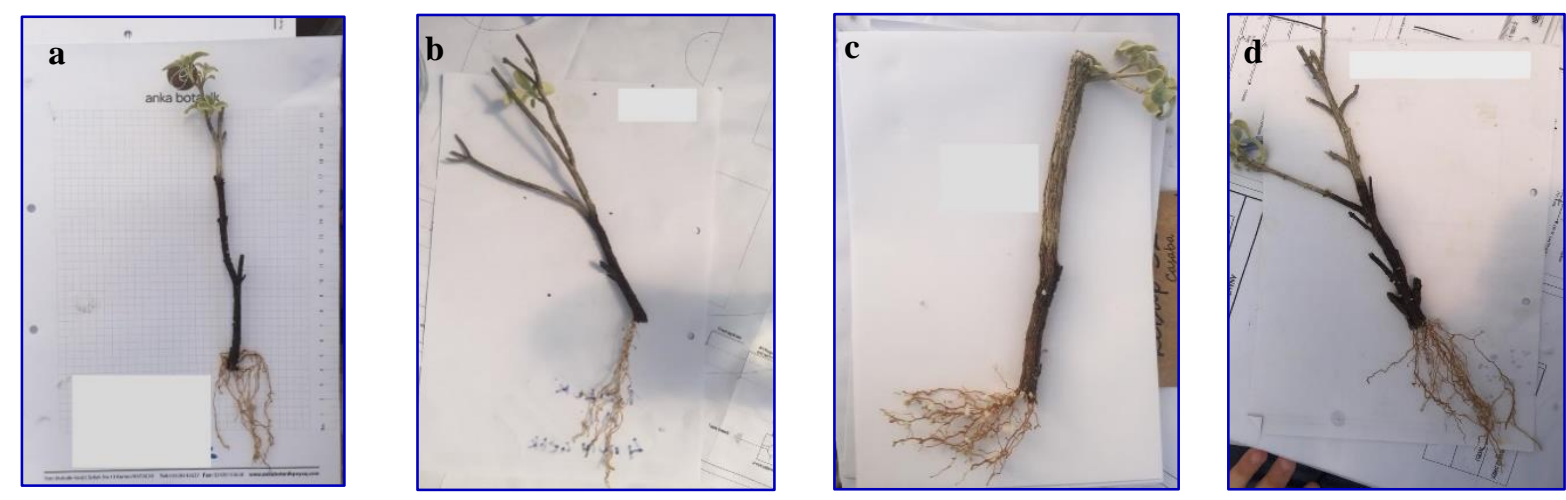

Şekil 3. P. chimerae türü rametleri (a) Kontrol Grubu rametlerinden bir örnek, (b) 1000 ppm IBA uygulanan rametlerinden bir örnek, (c) 3000 ppm IBA uygulanan rametlerinden bir örnek, (d) 5000 ppm IBA uygulanan rametlerinden bir örnek.

\subsection{Kök Sayısı}

Ortalamalar incelendiğinde $P$. chimerae türünde ortalama kök sayısının 7,05 olduğu ve bu sayının 1 ila 24 arasında varyasyon gösterdiği ve gruplar arasında istatistiki farkların olduğu belirlenmiştir. Kontrol grubu çeliklerinde kök sayısı ortalaması 5,76 iken, 1000 ppm IBA uygulanan çeliklerde bu sayı 6,16, 3000 ppm IBA uygulanan çeliklerde 6,33, 5000 ppm IBA uygulanan çeliklerde ise bu sayının 9,33 olduğu belirlenmiştir. Tablo 1'de görüldüğü gibi çeliklere uygulanan farklı IBA dozları arasında kök sayısı açısından en yüksek sayı 5000 ppm IBA uygulanan çeliklerde olup, genel olarak çeliklere uygulanan IBA dozu arttıkça kök sayısında artış olduğu gözlemlenmiştir. Benzer şekilde Sarı ve Kaçar (2019) biberiye (Rosmarinus officinalis L.) bitkisinin çeliklerinde uyguladıkları IBA dozlarının kök sayısı üzerine etkisi açısından aynı istatistiki grupta yer alarak 4500 ppm ve 2500 ppm dozlarında en yüksek kök sayısına sahip çelikler olduklarını belirlemişlerdir. Kara vd (2011) ise farklı IBA dozlarında biberiye, çördükotu ve adaçayı çeliklerinin en fazla kök sayısını 4000 ppm IBA dozundan elde ettiklerini bildirmişlerdir. Lamiaceae familyasına mensup bir diğer tür olan Lavandula stoechas türüne ait çeliklere uygulanan IBA dozlarının köklenmeyi olumlu yönde etkilediğini bildirilmiştir (Ayanoğlu vd, 2000).

\subsection{Kök Uzunluğu}

Çelik başına düşen ortalama kök uzunluğu incelendiğinde hormon dozları arasındaki ilişki istatistiki olarak önemli bulunmuştur $(\mathrm{p}<0,01)$. Kontrol grubu çeliklerinin kök uzunluk ortalaması $5 \mathrm{~cm}$ iken, 1000 ppm IBA uygulanan çeliklerde ortalamanın $6,97 \mathrm{~cm}, 3000 \mathrm{ppm}$ uygulanan çeliklerde ise 7,83 cm olduğu belirlenmiştir. Çeliklere uygulanan farklı IBA dozları arasında kök uzunluğu açısından en yüksek ortalama 5000 ppm IBA uygulanan çeliklerde (7,89 cm) olduğu belirlenmiştir. Tablo 1'de görüldüğü gibi çeliklere uygulanan IBA dozları arttıkça çeliklerin ortalama kök uzunluğu değerleri artmıştır. Yalnız çeliklere uygulanan IBA dozları arasında kök uzunluğu açısından istatistiki olarak anlamlı bir fark olmadığı, yalnızca kontrol grubu çelikleri ile IBA uygulanan çelikler arasında anlamlı bir farklılık olduğu tespit edilmiştir. Lamiaceae familyası üzerine yapılmış çalışmalardan bir diğeri olan Özcan vd (2013) Lavandula hybrida türüne ait yarı odun çeliklerinde farklı yetişme ortamlarının ve farklı IBA dozlarının kök sayısı (adet/çelik), kök uzunluğu (cm), köklenme oranı (\%) ve köklenme kalitesine olan etkilerini incelediği çalışmalarında, kök sayısı açısından 4000 ppm. tarla toprağında yetişen çeliklerde, kök uzunluğu ve köklenme kalitesi açısından en uzun ve en kaliteli köklü çeliklerin torf perlit karışımı köklenme ortamında 4000 ppm. dozunda IBA uygulanan çeliklerde olduğunu tespit etmiştir. Buna paralel olarak Ayanoğlu vd (2000) Lavandula stoechas türü çelikleriyle farklı IBA konsantrasyonlarının (1000, 2000 ve 4000 ppm) köklenme üzerine etkisini araştırdığı çalışmasında IBA konsantrasyonlarındaki artışa bağlı olarak köklenme yüzdesi, kök uzunluğu ve kök sayısının arttığını gözlemlemişlerdir. Benzer şekilde Kara (2011) farklı IBA dozları ve çelik alma dönemlerinin lavanta çeliklerinin kök sayısı, kök uzunluğu ve köklenme oranı üzerine etkilerini belirlediği araştırmasında, çalışılan tüm çeşitlerde en yüksek değerlerin Mart dönemi ve 4000 ppm IBA dozunda olduğunu belirlemiştir. 


\subsection{Kök Kuru Ağırlığı}

Kök kuru ağırlığı değerlerine bakıldığında en yüksek değerin 5000 ppm IBA uygulanan çeliklerde olduğu $(1,832$ gr.), bunu Kontrol grubu (0,847 gr.) ve 3000 ppm IBA uygulanan çeliklerin ( 0,702 gr.) takip ettiği belirlenmiştir. 1000 ppm IBA uygulanan çelikler $(0,65$ gr.) ise en düşük kök kuru ağırlığı ortalamasına sahip olan grup olduğu görülmüştür. Genel olarak çeliklere uygulanan IBA dozu arttıkça kök kuru ağırlığının da arttı̆ğ tespit edilmiştir. Benzer şekilde Sarı ve Kaçar (2019)'da biberiye (Rosmarinus officinalis L.) bitkisinin çeliklerinde uygulanan IBA dozları arttıkça kök kuru ağırlığında artış olduğunu tespit etmişlerdir.

\subsection{Ramet Kuru Ağırlığı}

Ramet kuru ağırlığı değerleri incelendiğinde ise kök kuru ağırlı̆ı̆ında olduğu gibi 5000 ppm IBA uygulanan çeliklerin (5,10 gr.) en yüksek çelik kuru ağırlık ortalamasına sahip olduğu belirlenmiştir. Kontrol grubu çeliklerinde bu ortalamanın 4,29 gr., 3000 ppm IBA uygulanan çeliklerde 4,05 gr. ve 1000 ppm IBA uygulananlarda ise 3,81 gr. olduğu belirlenmiş olup Tablo 1'de görüldüğü gibi istatistiki olarak farklı gruplar oluşmuştur. Bulgularımıza paralel olarak Biberiye (Rosmarinus officinalis) bitkisinin çeliklerinde uyguladıkları IBA dozları ramet kuru ağırlığı açısından değerlendirildiğinde 4500 ppm'de $2.43 \mathrm{~g}$ ile en yüksek değer elde edildiği belirtilmiştir (Sarı ve Kaçar, 2019). Bir diğer çalışma olan Selim ve Sever Mutlu (2018) Dorystoechas hastata türünde farklı IBA dozlarının çeliklerin köklenmesi üzerine etkilerini araştırdıkları çalışmalarında en yüksek ramet kuru ağırlığını 4000 ppm IBA uygulanan çeliklerde olduğu belirlemişlerdir.

\section{Sonuç ve Öneriler}

Kentsel peyzajların sürdürülebilirliğinin sağlanmasında doğal türlerin kullanımına yer verilmesi önemlidir. $\mathrm{Bu}$ kapsamda doğal türlerin uygun çoğaltım tekniklerinin belirlenerek fidanlıklardan temininin sağlanması gerekmektedir (Cengiz vd. 2013). Bu düşünceden yola çıkarak süs bitkisi sektörüne kazandırılabilecek birçok doğal türü florasında barındıran ülkemizde, bu türlerin tespit edilerek çoğaltım tekniklerinin belirlenmesi, karakterizasyon çalışmalarının yapılması, bu konudaki dışa bağımlılığımızın azaltılmasını sağlamanın yanında bitki genetik kaynakların korunması ve devamlılı̆ııın sağlanmasına da büyük fayda sağlayacaktır. Anavatanı ülkemiz olan ve doğal yayılışı Antalya olan endemik Phlomis chimeare türü sahip olduğu yapısal özellikleri ile süs bitkisi sektörüne kazandırılma potansiyeli yüksek nitelikte, kanaatkar bir türdür. Indol-3 bütirik asidin (IBA) farklı doz uygulamalarının türün yarı odun çeliklerinin köklenme özellikleri üzerine etkisinin belirlendiği bu çalışmada elde edilen tüm veriler değerlendirildiğinde köklenme özelliklerinin dozlara göre farklılık gösterdiği sonucuna varılmıştır.

Çeliklere uygulanan farklı IBA dozları arasında köklenme oranı incelendiğinde IBA dozları ile köklenme oranları arasında matematiksel olarak artı̧̧ olmasına rağmen bütün dozlar Duncan testi sonucuna göre aynı homojen grupta yer aldığından, köklenme oranı bakımından istatistiki olarak anlamlı fark bulunamamıştır. Kök sayısı, kök uzunluğu, kök ve ramet kuru ağırlı̆̆ değişkenlerinde ise en yüksek değerlerin 5000 ppm IBA uygulanan çeliklerinde olduğu belirlenmiştir. Genel olarak çeliklere uygulanan IBA dozu arttıkça KökSay, KökUz, KökKur, RamKur' da artış olduğu gözlemlenmiştir. Çalışmadan elde edilen sonuçlar $P$. chimerea türünün çelikle çoğaltımında IBA uygulamasının kök gelişimini olumlu yönde etkilediğini işaret etmektedir. Bundan sonra yapılacak çalışmalar ile daha yüksek dozlarda IBA uygulamaları ve IBA'nın yanında diğer köklenmeyi teşvik eden hormonların kullanımının etkileri incelenerek köklenmeyi arttırıcı olarak kullanılma potansiyellerinin belirlenmesi tavsiye edilmektedir.

\section{Kaynaklar}

1. Astorga, G.J., Nunez-Farfan, J. (2001). Effect of habitat fragmentation on the genetic structure of the narrow endemic Brongniartia vazquezii. Evolutionary Ecology Research, 3: 861-872.

2. Ayan, S., Yahyaoğlu, Z., Gerçek, V., Şahin, A., Sıvacioğlu, A. (2006). The Vegetative Propagation Possibilities by Soft Stem Cutting of Black Alder [Alnus glutinosa subsp. barbata (C. A. Mey.) Yalt.]. Pak. Journal of Biological Sciences, 9 (2): 238-242.

3. Ayan, S., Gedik, F., Yer Çelik, E.N., Gülseven, O., Yılmaz, E., Akın, Ş.S., Özel, H.B. (2020a). Morphological characteristics of some broad-leaved forest tree seedlings. Journal of Bartin of Faculty of Forestry, 22 (1): 245-255. 
4. Ayan, S., Civek, E., Yer Çelik, E.N., Gülseven, O., Akın, Ş.S., Yılmaz, E. (2020b). Morphological quality characteristics of Mediterranean and Arizona Cypresses seedlings. Journal of Bartın of Faculty of Forestry, 22 (2): 580-590.

5. Ayan, S., Civek, E., Yer Çelik, E.N., Gülseven, O., Özel, H.B., Eshaibi, J.A.H., Akın, Ş.S., Yılmaz, E. (2020c). Morphological quality characteristics of different ages containerised seedlings of stone pine (Pinus pinea L.). Journal of Bartin of Faculty of Forestry, 22 (2): 633-641.

6. Ayan, S., Sivacioğlu, A. (2006). Review of the fast growing forest tree species in Turkey. The Bulletin CIDEU, 2: 57-71.

7. Ayanoğlu, F., Mert, A., Kaya, A. (2000). Hatay florasında yetişen Karabaş Lavantanın (Lavandula stoechas subsp. stoechas L.) çelikle köklendirilmesi üzerine farklı lokasyonların ve hormon dozlarının etkisi. Turk J. Agric. Forest., 24, 607-610.

8. Bekçi, B., Var, M., Taşkan, G. (2017). Bitkilendirme tasarım kriterleri bağlamında doğal türlerin kentsel boşluk alanlarında değerlendirilmesi: Bartın, Türkiye. Artvin Çoruh Üniversitesi Orman Fakültesi Dergisi, 14(1): 113-125.

9. Cengiz, B., Bekci, B., Cengiz, C. (2013). Bartın Kent Kullanıcılarının Süs Bitkilerine Olan Talebinin İrdelenmesi. V. Süs Bitkileri Kongresi (6-9 Mayıs 2013) Bildiriler Kitabı, s. 560-565, Yalova.

10. Cengiz, B., Keçecioğlu Dağlı, P., Yiğittekin, S. (2017). Peyzaj ekonomisi açısından peyzaj ve süs bitkileri fidanlık işletmelerine yönelik sektörel bir analiz. Bartın Orman Fakültesi Dergisi, 19(2): 50-62.

11. Çelik, S., Göktürk, R.S., Flamini, G., Cioni, P.L., Morelli, I. (2015). Essential oils of Phlomis leucophracta, Phlomis chimerae and Phlomis grandiflora var. grandiflora from Turkey. Biochemical Systematics and Ecology, 33: 617-623.

12. Davidson, H., Peterson, C., Mecklenburg, R. (1994). Nursery Management- Administration and Culture. Third Edition New Jersey, USA: Prentice Hall Career \& Technology.

13. Davies, F.T., Geneve, R.L., Wilson, S.B., Hartman, H.T., Kester, D.E. (2017). Hartmann and Kester's Plant Propagation Principles and Practices. New York, USA: Pearson Education, Inc.

14. De Klerk, G., Van der Krieken, W., De Jong, J.C. (1999). Review the formation of adventitious roots: New concepts, new possibilities. In Vitro Cell. Dev.Biol.-Plant, 35, 189-199.

15. Deniz, İ.G., Aykurt, C. (2016). Antalya Endemik ve Nadir Çiçekleri. Antalya: Kutlu \& Avcı Ofset.

16. Dinçer, D., Bekçi, B., Bekiryazıcı, F. (2016). Türkiye'deki doğal bitki türlerinin üretiminde doku kültürü tekniklerinin kullanımı. Nevşehir Bilim ve Teknoloji Dergisi, 2, 295-302.

17. Eroğlu, E., Akıncı Kesim, G., Müderrisoğlu, H. (2005). Düzce kenti açık ve yeşil alanlarındaki bitkilerin tespiti ve bazı bitkisel tasarım ilkeleri yönünden değerlendirilmesi. Tarım Bilimleri Dergisi, 11, 270-277.

18. Girmen, B., Karagüzel, O. (2005). Gazipaşa (Antalya) yöresi doğal Hayıt'larının (Vitex agnus-castus L.) seleksiyonu-I: Seçilen tiplerin özellikleri. Akdeniz Üniversitesi Ziraat Fakültesi Dergisi, 18, 385-396.

19. Göktürk, R.S. (2015). Phaselis antik kenti florası I. Phaselis Disiplinlerarası Akdeniz Araştırmaları Dergisi, $1,81-131$.

20. Frankham, R. (1997). Do island populations have less genetic variation than mainland populations? Heredity, 7, 311-327.

21. Haag, T.N., Santos, A.S., Sana, D.A., Morato, R.G., Cullen, J.R., Crawshaw, P.G., De Angelo, J.C., Di Bitetti, M.S., Salzano, F.M., Eizirik, E. (2010). The effect of habitat fragmentation on the genetic structure of a top predator: loss of diversity and high differentiation among remnant populations of Atlantic Forest jaguars (Pantheraonca). Molecular Ecology, 19 (22): 4906-4921.

22. Hamner, R.M., Pichler, F.B., Heimeir, D., Constantine, R., Baker, C.S. (2012). Genetic differentiation and limited gene flow among fragmented populations of New Zealand endemic Hector's and Maui's dolphins. Conserv Genet., 13, 987-1002.

23. İzgi, M.N. (2020). Farklı IBA (İndol-3-Bütirik Asit) dozları ve köklendirme ortamlarının bazı tıbbi bitkilerin köklenmesi üzerine etkileri. Turk J Agric Res, 7(1): 9-16.

24. Kara, N. (2011). Uçucu Yağ Üretimine Uygun Lavanta (Lavandula sp.) Çeşitlerinin Belirlenmesi ve Mikroçoğaltım Olanaklarının Araştırılması. Doktora Tezi, Süleyman Demirel Üniversitesi, Fen Bilimleri Enstitüsü, Tarla Bitkileri Anabilim Dalı, Isparta, $161 \mathrm{~s}$.

25. Kara, N., Baydar, H., Erbaş, S. (2011). Farklı çelik alma dönemleri ve IBA dozlarının bazı tıbbi bitkilerin köklenmesi üzerine etkileri. Batı Akdeniz Tarımsal Araştırma Enstitüsü Derim Dergisi, 28 (2): 71-81.

26. Karagüzel, O. (1997). Gelin duvaklarının (Bougainvillea sp.) çelikle çoğaltılması üzerinde araştırmalar. Akdeniz Üniversitesi Ziraat Fakültesi Dergisi, 10, 109-118.

27. Kesici, A., Haspolat, G., Oğuz, B. (2010). Ülkemiz florasında doğal olarak yayılış gösteren süs bitkilerinin survey toplanması, muhafazası ve değerlendirilmesi. Anadolu J. of AARI, 20(2): 89 - 95.

28. Koçak, M. (2006). Bazı Sorbus L. (Üvez) Türleri Tohumlarının Çimlenme ve Fidecik Gelişimi Üzerine Hormonal İşlemin Etkisi. Yüksek Lisans Tezi, Gazi Üniversitesi, Fen Bilimleri Enstitüsü, Orman Mühendisliği Anabilim Dalı, Ankara, $81 \mathrm{~s}$.

29. Menges, E.S. (1986). Predicting the future of rare plant populations: demographic monitoring and modelling. Natural Areas Journal, 6, 13-25. 
30. Özcan, İ.İ., Arabacı, O., Öğretmen, N.G. (2013). Lavanta (Lavandula hybrida)'nın Köklenmesi Üzerine Farklı Hormon Dozları ve Köklendirme Ortamlarının Etkisi. V. Süs Bitkileri Kongresi (6-9 Mayıs 2013) Bildiriler Kitab1, s. 529-534, Yalova.

31. Özer, E., Kalyoncu, İ.H. (2007). Gilaburu (Viburnum opulus L.)'nun yeşil çelikle çoğaltma imkanlarının araştırılması. Selçuk Üniversitesi Ziraat Fakültesi Dergisi, 21(43): 46-52.

32. Sarı, D., Karaşah, B. (2018). Bitkilendirme Tasarımı Öğeleri, İlkeleri ve Yaklaşımlarının Peyzaj Tasarımı Uygulamalarında Tercih Edilirliği Üzerine Bir Araştırma. Megaron, 13(3): 470-479.

33. Sarı, Y., Kaçar, O. (2019). Biberiye (Rosmarinus officinalis L.) çeliklerinde köklenme üzerine farklı köklendirme ortamları ve IBA dozlarının etkileri. Bahçe, 48(1), 27-37.

34. Sarıkaya, A.G. (2015). Göller Yöresi Doğal Phlomis L. (Lamiaceae) Taksonlarının Farklı Toplama Zamanlarının ve Bazı Yetişme Ortamı Özelliklerinin Uçucu Bileşenleri Üzerine Etkisi. Doktora Tezi, Süleyman Demirel Üniversitesi, Fen Bilimleri Enstitüsü, Orman Mühendisliği Anabilim Dalı, Isparta, $310 \mathrm{~s}$.

35. Schemske, D.W., Husband, B.C., Ruckelshaus, C.G., Goodwillie, C., Parker, I.M., Bishop, J.G. (1994). Evaluating approaches to the conservation of rare and endangered plants. Ecology, 75, 584-606.

36. Selim, C., Sever Mutlu, S. (2018). Vegetative Propagation of a Relict Endemic Medicinal And Aromatic Plant of Antalya-Turkey, Dorystoechas hastata Boiss. \& Heldr. Ex Bentham (Lamiaceae). 4th International Symposium of Medicinal and Aromatic Plants (2-4 October 2018), pp. 325-330, Çeşme, İzmir.

37. Sever Mutlu, S., Yıldız, F., Selim, C. (2013). Hayıt (Vitex agnus castus L.) Bitkisinin Çelikle Üretilmesine Bitki Büyüme Düzenleyicilerinin Etkisi, V. Süs Bitkileri Kongresi (6-9 Mayıs 2013), s. 499-504, Yalova.

38. Sıvacıŏ̆lu, A., Ayan, S., Ergin, Ö.F., Ertekin, M. (2004). Grafted-Seedling production of Pyramid-like Black Pine (Pinus nigra subsp. pallasiana var. pyramidata). Journal of Forestry Faculty of Gazi University, 4 (2): 232-242.

39. Şeker, M., Akçal, A., Sakaldaş, M., Gündoğdu, M.A. (2010). Farklı çelik alma dönemleri ile oksin dozlarının kocayemişin (Arbutus unedo L.) köklenme oranı üzerine etkilerinin belirlenmesi. Uludăg Üniversitesi Ziraat Fakültesi Dergisi, 24(1): 99-108.

40. Torun Kayabaşı, E. (2018). Kentsel Tasarımda Doğal Bitkilerin Kullanımı ve Ekonomik Önemi. ISUEP Uluslararası Kentleşme ve Çevre Sorunları Sempozyumu: Değişim/Dönüşüm/Özgünlük (28-30 Haziran 2018) Bildiriler Kitab1, Cilt 2, s. 77-84, Eskişehir.

41. Yahyaoğlu, Z., Ayan, S., Gerçek, V., Şahin, A. (2002). Rooting Experiments on the cuttings of Alnus glutinosa subsp. barbata, 2nd National Black Sea Forestry Congress (15-18 May 2002), Vol 2, pp.423-430, Artvin.

42. Yazıcı, K., Gülgün, B. (2016). TR83 illerinde süs bitkileri sektörünün mevcut durumu ve geliştirilmesi üzerine bir araştırma. Selçuk Tarım Bilimleri Dergisi, 3(1): 18-24.

43. Yer, E.N., Ayan, S. (2013). Türkiye Orman Fidanlıklarında Yetiştirilen Süs Bitkilerinin Üretim Teknikleri. V. Süs Bitkileri Kongresi (6-9 Mayıs 2013) Bildiriler Kitab1, s. 641-646, Yalova.

44. Yıldıztekin, M., Ulusoy, H., Tuna, A.L. (2019). Türkiye'de Tıbbi ve Aromatik Bitkilerin Yetiştiriciliği ve Sürdürülebilir Gelişimi, 4 th International Symposium on Innovative Approaches in Engineering and Natural Sciences (22-24 Kasim 2019), 4(6), pp. 481-484, Samsun. 